Pemahaman Guru Kelas.... (Adrianus Dedy)

\title{
PEMAHAMAN GURU KELAS DALAM MENJALANKAN PERAN SEBAGAI PEMBIMBING
}

\author{
Oleh: Adrianus Dedy \\ (Dosen Universitas PGRI Palembang) \\ Email: adrianusdedy@univpgri-palembang.ac.id
}

\begin{abstract}
Abstrak
Salah satu fungsi guru kelas adalah sebagai pembimbing, fungsi tersebut perlu dipahami dan dimaksimalkan oleh guru kelas, terutama jika melihat semakin beragamnya permaslahan siswa. SD Xaverius 7 Palembang merupakan sekolah yang pernah mendapatkan workshop mengenai implementasi layanan BK di SD, oleh karena itu perlu disurvey bagaimana pemahaman guru kelas dalam menjalankan fungsi sebagai pembimbing. Penelitian survey dilakukan terhadap guru kelas 4, 5, dan 6 SD Xaverius 7. Hasil penelitian menunjukkan bahwa guru kelas memiliki pemahaman yang tinggi dalam menjalan kan pemahaman terhadap peserta didik, yaitu $70 \%$. Sementara itu guru kelas masih kebingungan dalam merancang rencana operasional yang terintergrasi dengan materi pada RPP, melakukan konseling, dan mengembangkan media. Penelitian merekomendasikan sekolah untuk memaksimalkan kolaborasi dalam pengembangan materi, serta memaksimalkan komunikasi antara guru kelas dengan orang tua melalui perangkat teknologi sebagai bagian dalam pengentasan masalah.
\end{abstract}

Kata Kunci: Peran, Guru Kelas, Pembimbing

\section{CLASS TEACHER COMPREHENSION IN CARRYING OUT A GUIDANCE FUNCTION}

\begin{abstract}
One of the functions of the teacher in the class is a guidance function, the function needs to be understood and maximized by the class teacher, especially when looking at the growing variety of students. SD Xaverius 7 Palembang is a school that has received a workshop on the implementation of the guidance service in elementary school, therefore it is necessary to be surveyed how the understanding Research survey conducted on the teachers of Grade 4, 5, and 6 $S D$ Xaverius 7. The results showed that the class teacher had a high understanding of the understanding of the learners, i.e. 70\%. Meanwhile, classroom teachers are still confused in designing operational plans that are integrated with material on RPP, counseling, and developing media. Research recommends schools to maximize collaboration in material development, as well as maximizing communication between class teachers and parents through technology devices.
\end{abstract}

Keywords: Role, Cass Teaccher, Guidance Funtion 


\section{A. PENDAHULUAN}

Permasalahan siswa sekolah dasar semakin beragam mulai dari permasalahan klasik seperti malas berlajar dan kurang disiplin, hingga persoalan ekstrem seperti bullying, menyakiti diri, dan adiksi gawai. Dalam situasi seperti saat ini layanan bimbingan dan konseling diperlukan untuk mengatasi persoalanpersoalan tersebut. Siswa dapat difasilitasi dalam melatih keterampilan hidup sehari hari, memiliki kebiasaan yang baik, dan dapat mengelola dirinya.

Penelitian terdahulu yang dilakukan Setianingsih (2016) menunjukkan beberapa permasalahan siswa SD yang lazim terjadi seperti berbohong, meninggalkan kelas tanpa izin, mencontek, kurang disiplin, dan lain sebagainya disebabkan oleh sikap dan cara belajar yang salah, dan bimbingan konseling diperlukan untuk mengembangkan sikap belajar. Dalam penelitiannya pun ditegaskan bahwa bimbigan dan konseling perlu diintergrasikan dengan kegiatan belajar mengajar, yang berupa pembentukan kebiasaan dan sikap belajar yang baik.

Hingga saat ini bimbingan dan konseling di Sekolah Dasar (SD) sangat minim dimiliki oleh lembaga pendidikan. Sementara itu, pemerinntah Indonesia pun menaruh perhatian akan pentingnya layanan bimbingan dan konseling di SD, dibuktikan dengan adanya Permendikbud Nomor 111 tahun 2014, tentang Bimbingan dan Konseling pada Pendidikan Dasar dan Pendidikan Menengah (Suryahadikusumah \& Dedy, 2019). Pada tahun 2016 pun panduan operasional layanan BK di SD sudah diterbitkan.

Dalam Panduan Operasional Penyelenggaraan BK di SD (POP BK - SD), terdapat berapa alternatif penyelenggara layanan BK di SD antara lain : 1) Guru BK atau konselor di SD ditugaskan di setiap sekolah atau di tingkat gugus sekolah, 2) Guru BK di tingkat gugus yang berkantor di sekolah induk yang ditetapkan oleh Dinas Pendidikan Kabupaten/Kota. dan 3) Guru BK dapat ditugaskan di UPTD Pendidikan atau unit pendidikan yang setingkat (Farozin et.al, 2016). Sayangnya, secara teknis belum sepenuhnya diturunkan pada kebijakan teknis kepada dinas pendidikan di daerah, hingga unit sekolah, sehingga penyelenggara layanan BK sampai saat ini dibebankan kepada guru/wali kelas. 
Jika kembali melihat undang - undang no 14 tahun 2005, tentang guru dan dosen, ditegaskan juga bahawa fungsi utama guru adalah mengajar, mendidik, membimbing, mengarahkan, melatih, menilai, dan mengevaluasi peserta didik. Suparlan (2008) menjelaskan bahwa fungsi guru dalam membimbing berfokus kepada pengenalan norma yang berlaku, memotivasi siswa, dan melakukan strategi pembinaan.

Lianawati (2018) menjelaskan secara rinci beberapa tugas yang harus dilaksanakan guru kelas sebagai pembimbing.

1. Melakukan pemahaman terhadap peserta didik secara mendalam (asesmen)

2. Menyusun rencana operasional dalam menyelenggarakan layanan dasar

3. Melakukan layanan langsung (konseling, bimbingan klasikal, bimbingan kelompok, alih tangan kasus, kolaborasi dan konsultasi, home visit, advokasi, dan case conference).

4. Pengembangan media layanan ( kepustkaan, liflet, pengembangan media inovatif).

5. Melakukan evaluasi dan tindak lanjut terhadap hasil layanan BK.

Guru kelas di SD Xaverius 7 pada tahun 2018 telah diberikan Workshop Implementasi POP BK di SD. Idealnya guru kelas di sekolah tersebut memiliki pemahaman dan kemampuan dalam menjalan kan fungsinya sebagai pembimbing baik secara konseptual maupun praktik di kelas sesuai dengan arahan pada panduan operasional yang telah dilatihkan sebelumnya. Oleh karena itu penelitian ini dilakukan untuk kembali mengevaluasi ketercapain program pada penelitian terdahulu mengenai implementasi layanan BK di SD.

\section{B. METODOLOGI PENELITIAN}

Penelitian dilakukan dengan melakukan survey kepada guru kelas 4,5, dan 6 SD Xaverius 7 Palembang. Subjek penelitian merupakan guru yang telah mengikuti kegiatan Workshop Implementasi POP BK di SD. Survey bertujuan untuk mengevaluasi ketercapaian tujuan pemberian workhsop, yaitu seberapa 
paham guru kelas dalam menjalankan fungsi sebagai pembimbing baik secara kognitif dan praktik di kelas.

Tingkat pemahaman diukur menggunakan angket. Katgorisasi tingkat pemahaman guru dilakukan dengan membagi pada tiga kategori yaitu tinggi, sedang, dan rendah. Pengkategorian menggunakan distribusi frekwensi berdasarkan presentase skor.

\section{HASIL PENELITIAN DAN PEMBAHASAN}

Hasil survey mengenai pemahaman guru kelas dalam menjalankan fungsi sebagai pembimbing disajikan pada tabel 1 di bawah ini.

Tabel 1. Hasil Survey

\begin{tabular}{|l|l|l|l|l|l|}
\hline Kategori & $\begin{array}{l}\text { Melakukan } \\
\text { Pemahaman } \\
\text { Pada Peserta } \\
\text { Didik }\end{array}$ & $\begin{array}{l}\text { Menyusun } \\
\text { Rencana } \\
\text { Operasional }\end{array}$ & $\begin{array}{l}\text { Melakukan } \\
\text { Layanan } \\
\text { Langsung }\end{array}$ & $\begin{array}{l}\text { Pengemba- } \\
\text { ngan Media } \\
\text { Layanan }\end{array}$ & $\begin{array}{l}\text { Melakukan } \\
\text { Evaluasi dan } \\
\text { Tindak } \\
\text { Lanjut }\end{array}$ \\
\hline Tinggi & 70 & 0 & 65 & 30 & 50 \\
\hline Sedang & 20 & 0 & 25 & 60 & 30 \\
\hline Rendah & 10 & 100 & 10 & 10 & 20 \\
\hline
\end{tabular}

Berdasarkan data pada tabel 1 tingkat pemahaman paling tinggi yang dimiliki guru adalah mengenai melakukan pemahaman pada peserta didik. $70 \%$ guru kelas memahami cara melakukan pemahaman pada peserta didik. Secara umum mereka melakukan observasi pada perilaku siswa, dan mencari data tambahan dengan melakukan wawancara.

Aspek menyusun rencana operasional layanan merupakan aspek yang paling tidak dipahami oleh seluruh guru kelas. Guru kelas mengakui kebingungan ketika harus membuat rencana operasional secara administrasi dikarenakan tidak adanya tuntutan dari kepala sekolah maupun pengawas. Dalam panduan operasional pun tidak diberikan contoh rencana operasional layanan yang terintegrasi dengan RPP.

Aspek terendah kedua adalah pengembangan media layanan. $30 \%$ guru memiliki pemahaman dalam mengembangkan media layanan . $70 \%$ lainnya tidak 
memahami cara dan media apa yang harus dibuat sebagai media layanan. Bentuk media layanan yang dikembangkan oleh guru adalah membuat kata kata motivasi dan mading karya siswa sebagai media pengembangan diri siswa.

Layanan langsung dan evaluasi tindakan secara umum dipahami oleh guru kelas. Beberapa strategi layanan dan evaluasi telah biasa dilakukan lama seperti memberikan motivasi pada siswa, melakukan home visit, melakukan konsultasi dengan orang tua. Strategi yang belum dipahami oleh guru kelas adalah melakukan bimbingan melalui permainan dan melakukan konseling dalam pengentasan masalah.

\section{PEMBAHASAN}

Berdasarkan hasil survey, pengembangan materi dan rencana operasional layanan menjadi perhatian utama. Ada baiknya guru kelas bersama sama menyusun operasional, baik antar guru kelas, bahkan dapat dipimpin langsung oleh kepala sekolah. Pada kenyataannya memang secara operasional tidak ada tuntunan dari gugus ataupun dinas pendidikan setempat mengenai penyusunan materi bimbingan bagi siswa. Layaknya pengelolaan pendidikan secara umum, kepala sekolah yang harus menjadi pemimpin dalam merancang program pendidikan di sekolah secara umum, guru kemudian menguraikannya pada setiap rencana kegiatan di kelas.

Silitonga et. al. (2014) mendeskripsikan kegiatan perencanaan bimbingan di SDN 2 Rowosari melibatkan kepala sekolah, guru kelas dan guru bidang studi. Dalam pertemuan tersebut disampaikan profil dan karakteristik pribadi siswa yang perlu dikembangkan secara maksimal, sepertimematuhi tata tertib sekolah serta berakahlak mulia, demokratis dan juga bertanggungjawab.

Selanjutnya, berkenaan dengan kesiapan guru kelas dalam melaksanakan layanan konseling dapat dilakukan dengan mengikuti kursus / pendidikan khusus mengenai intervensi play \& expressive art therapy. Henderson (2011) berpendapat bahwa kedua intervensi tersebut merupakan strategi utama dalam konseling anak, dan dapat diintergrasikan dalam konseling keluarga seperti 
dengan melakukan psikodrama, family drawing, family sclupture, dan genogram. Sesuai dengan pandangan guru-guru bahwa permasalahan anak memerlukan kerjasama dan peran orang tua dalam pengentasannya.

Guru kelas dituntut kreatif dalam berkomunikasi dengan siswa, sehingga dalam pengentasan masalah siswa dapat terlibat dan tidak merasa disalahkan. Komunikasi yang dilakukan guru kelas dalam membimbing bertujuan agar siswa memahami tujuan dari setiap perilaku yang ingin dilakukannya. Hal tersebut menjadi penting karena ada kecenderungan guru lebih sering memberikan instruksi kepada siswa, dengan alasan siswa di kelas pandai mencari alasan ketika melakukan pelanggaran. Sesuai dengan yang ditemukan juga dalam penelitian Martanti (2015) bahwa Anak-anak seusia kelas 4, 5 dan 6 cenderung lebih berani dan mulai memiliki argumentasi sendiri yang berbeda dengan guru maupun orang tuanya.

Suryahadikusumah \& Dedy (2019) merekomendasikan jika kegiatan konseling mengentaskan masalah siswa tidak dikuasiai, konsultasi antara guru kelas dengan orang tua/wali siswa harus dioptimalkan, karena diasumsikan penyelesaian lebih akurat apabila melibatkan peran orangtua. Dengan perkembangan teknologi saat ini guru kelas dapat memaksimalkan group whatsapp kelas yang diikuti oleh seluruh orang tua / wali murid, dalam group tersebut guru kelas dapat melaporkan dan memantau perkembangan siswa baik di sekolah maupun di rumah.

\section{SIMPULAN}

Hasil penelitian menunjukkan bahwa guru kelas memiliki pemahaman dalam menjalan kan fungsi sebagai pembimbing yang tinggi pada aspek melakukan pemahaman terhadap peserta didik, yaitu $70 \%$. Guru kelas cukup memahami stretegi dalam melakukan layanan langsung dan melakukan evaluasi. Sedangkan aspek paling rendah adalah mengembangkan rencana operasional yang terintegrasi dengan RPP, serta pengembangan media layanan. 
Penelitian merekomendasikan dalam menjalankan fungsi sebagai pembimbing, sekolah dapat memaksimalkan kolaborasi antar guru kelas dalam pengembangan materi dan rencana operasional bimbingan dalam RPP, dan kolaborasi dengan orang tua dalam upaya pengentasan masalah. Guru kelas pun dapat memaksimalkan komunikasi dengan orang tua melalui perangkat teknologi.

\section{DAFTAR PUSTAKA}

Farozin, M., Suherman, U., Triyono, Purwoko, B., Hafina, A., Yustiana, Y. R., \& Sukmaja. (2016). Panduan Operasional Penyelenggaraan Bimbingan dan Konseling Sekolah Dasar (SD). Jakarta: Direktorat Jenderal Guru dan Tenaga Kependidikan Kementerian Pendidikan dan Kebudayaan Republik Indonesia.

Henderson, Donald A,. (2011). Counseling Children 8 Edition. USA : Brooks/ Cole

Martanti, F. (2015). Peran Guru Kelas Dalam Memberikan Layanan Bimbingan Dan Konseling Di SDN Watuaji 01 Kabupaten Jepara. Magistra, 6(2), 1831.

Lianawati, A. (2018). Identifikasi Kesiapan Guru Kelas Dalam Melaksanakan Layanan BK di SD. Buana Pendidikan: Jurnal Fakultas Keguruan dan Ilmu Pendidikan, 14(25), 96-102.

Setianingsih, E. S. (2016). Peranan Bimbingan Dan Konseling Dalam Memberikan Layanan Bimbingan Belajar Di SD. Malih Peddas (Majalah Ilmiah Pendidikan Dasar), 6(1).

Silitonga, A. S., Sarjono, Y., \& Anif, S. (2014). Pengelolaan Kegiatan Bimbingan dan Konseling untuk Pembentukan Karakter Siswa Sekolah Dasar.

Suparlan. (2008). Menjadi Guru Efektif. Yogyakarta: Hidayat.

Suryahadikusumah, A. R., \& Dedy, A. (2019). Implementasi layanan bimbingan dan konseling di sekolah dasar untuk mengembangkan kemandirian siswa. Premiere Educandum: Jurnal Pendidikan Dasar Dan Pembelajaran, 9(1), 44. 